Nunt. Antiquus, Belo Horizonte, v. 15, n. 1, p. 77-98, 2019

\title{
Melpômene, cantar e dançar tragicamente
}

\section{Melpomene, Singing and Dancing Tragically}

\author{
Francisco Marshall \\ Universidade Federal do Rio Grande do Sul (UFRGS), Porto Alegre, Rio Grande do \\ Sul / Brasil \\ marshall@ufrgs.br
}

Resumo: Após a análise histórica e fenomenológica do fenômeno cultural Musas, a partir do mito grego representado em Homero e Hesíodo, examina-se a constituição das propriedades alegóricas e simbólicas da Musa Melpômene, e sua expressão nas iconografias antigas e modernas.

Palavras-chave: mito; Musa; Melpômene; Jaa Torrano; iconologia.

Abstract: After the historical and phenomenological analysis of the Muses as a cultural phenomenon, according to the Greek myth represented in Homer and Hesiod, this paper will examine the constitution of the allegorical and symbolic attributes of the Muse Melpomene, as well as its expression in Ancient and Modern iconographies.

Keywords: myth; Muse; Melpomene; Jaa Torrano; iconology.

\section{Musas?}

As Musas conectam o divino ao histórico e dão sentido ao mundo, com elaboração estética, cantando e dançando, transmitindo imagens que enlevam os sentidos e elevam a mente. Eis como os gregos conceberam o culto às Musas, filhas de Zeus e Mnemosýne (Memória), por meio de uma trama mítica tocando verdade, sacralidade, mundo divino, condição humana, conhecimento, arte e sociedade. Coreográficas, as Musas 
impregnam o mundo com sua performance, transformam a condição humana pelo dom de visões e saberes, e garantem a sobrevivência das memórias que constituem a cultura. A anterioridade deste mito e a posição de autoridade que os mais sagrados poemas gregos dão às Musas são testemunho de seu prestígio desde as origens, e de sua longa e significativa história na cultura grega.

Em Homero e Hesíodo, podemos conhecer estes fundamentos, e compreender algo da potência das Musas. Apenas algo, pois o conhecimento pleno só é possível mediante uma interpelação das deusas, que não costumam inocular seu canto em textos de análise cultural, como este. Mas podemos nos aproximar da fonte épica, e beber algo de sua potência genética. Para este retorno à origem, devemos desconsiderar, provisoriamente, as imaginações posteriores, na poesia lírica, entre os trágicos e, sobretudo, entre os eruditos alexandrinos, bem como em toda a recepção romana, renascentista e póstera.

Preliminarmente, é preciso destituir as Musas de muitos dos atributos com que se consagraram desde a antiguidade, identificando-as como símbolos de alguns gêneros de artes e ciências.

No momento em que os primeiros poetas gregos formularam o mito das Musas, ainda não existiam muitos dos gêneros associados às Musas; os epígonos do canto épico viveram entre os séculos IX e VII a.C., ao passo que a História, associada a Clio, surge apenas no século V a.C., na obra de Heródoto; o mesmo com Erato, Musa do canto lírico, uma geração adiante de Hesíodo, e Talía e Melpômene, Musas de Comédia e Tragédia, artes da Atenas clássica, distantes no mínimo 150 anos da era épica. Urânia, ou Celeste, é estampa da Astronomia, mas refere melhor uma visão astrológica do mundo, em que a dimensão celestial preside ao mundo terreno, e dá a ele destino cósmico articulado aos astros perfeitos - um efeito da cultura babilônica na aurora da imaginação grega. Estas alegorias fazem sentido, e logo as examinaremos, mas o recuo da análise nos leva a circunstância genética ainda mais potente do que a tardia simbolização alegórica.

Primeiramente, a função das Musas. Para esta compreensão, serve-nos o privilégio de termos acesso a um dos textos mais importantes 
da história do classicismo: o ensaio "O mundo como função das Musas", de Jaa Torrano (1995), que precede sua tradução da Teogonia de Hesíodo. Tal como os proêmios antigos, que evocavam a Musa para ter acesso à memória olímpica, este ensaio é a chave para termos acesso à inteligência do mito antigo, e compreendermos como ele se manifesta no canto e dança das Musas. Trata-se de compreender a natureza e efeitos de um discurso que contempla a posição do homem no mundo e a misteriosa interpelação do sagrado. Aedos e rapsodos, dotados de um kydos (dote) e um géras (talento) que os habilita ao serviço das Musas, tornam-se veículos de um contato com a verdade divina, olímpica, celebrada como mito e glória, performance e fama, poder e história. Entende-se, nisto, que há um grau superior da verdade, olímpico, e este é conhecido das Musas, transmitido por seus núncios e assim oferecido aos mortais homens, em ambiente cerimonial.

\section{As verdades das Musas}

As Musas sabem do que é relevante: os fatos e feitos notáveis no mundo, realizados por deuses e heróis. No caso heroico, tratam-se de evidências da virtude (areté), que merecem glória (kléos); tal como a fumaça dos sacrifícios, ascende ao Olimpo o brilho de virtudes notáveis, como a piedade, a bravura e a prudência. A imagem dos feitos brilhantes ergue-se e vai encantar aos festins olímpicos, animados pelo canto e dança das Musas, as quais, benevolamente, concedem memória daqueles cantos também aos mortais, desde que consigam perceber e compreender a interpelação divina. Há neste mito, portanto, uma dimensão de verdade sagrada e de seu meio de propagação, e uma forte noção de sociedade, espelhada nos valores e ambições da aristocracia guerreira homérica e na elevada dignidade então desfrutada por profetas e rapsodos. "Pastores agrestes, vis infâmias e ventres só,/ sabemos muitas mentiras dizer, símeis aos fatos/ e sabemos, se queremos, dar a ouvir revelações" (HESÍODO. Teogonia, v. 26-28). 
A ambiguidade de mentira e verdade do canto das Musas exige do interpelado (cantor, ouvinte, espectador) sua qualidade de argúcia, para discernir o que se revela no mito; é o desafio semiológico do mito antigo, parte de uma epistemologia desafiadora. Em sua forma ideal, todavia, a palavra das Musas, musical e coreográfica, é inoculada na mente do cantor sob a forma de possessão, em um processo ritual em que o sujeito da narrativa, autor e garantidor de verdade e beleza, é a Musa, e o cantor, seu servo. Eis porque as obras épicas começam sempre com um hino de evocação à Musa, o proêmio, para que esta atenda ao rogo e conceda a beleza e verdade do canto. Esta evocação é o rito que antecede a possessão poética, na qual o aedo, veículo do canto, atua tal como o médium (ou cavalo) no transe espírita, porém, no caso grego, com a qualidade de obras de arte máximas, repletas de sentidos, efeitos, beleza, imagens e pensamentos, e tendo como agente da possessão a uma (ou várias) potência(s) divina(s) do mais alto e propício poder.

A celebração em canto e dança: as Musas produzem uma performance festiva, que se expande pelo espaço em uma evolução coreográfica, como dança de roda em cujo centro está um axis mundi, eixo do mundo, conectando a celebração com as diversas dimensões do kósmos organizado orbitalmente, mundos ctônico, terreno e celestial. No centro, o mundo social do canto e da dança, parte de uma festividade litúrgica, pública, na paisagem, junto a altares de Zeus. "A dança em volta da fonte (v. 3 e 4) é uma prática de magia simpatética, com que o pensamento mítico analógico crê garantir a perenidade do fluxo da fonte" (TORRANO, 1995, p. 22). 
FIGURA 1 - Apolo e as Musas - que coreografia, que festa! /

Lécito proveniente de Tanagra, do pintor de Safo

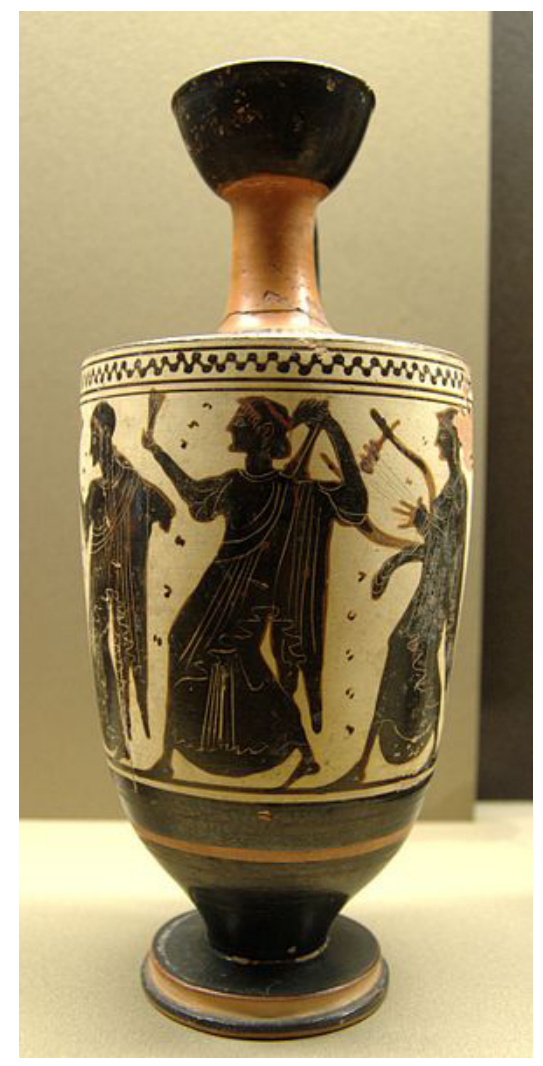

Fonte: Wikimedia Common Contributors.

Apollo Mousai Louvre, 2019.

Há potente dimensão estética nesse fenômeno coreográfico. O mito das Musas nos diz que as formas elementares da cultura, propagadas pelas filhas de Memória (Mnemosýne) e Zeus, são formas sensíveis, estéticas, performáticas, coreográficas. Isto é o que nos leva a rememorar as Musas por suas funções e identidades estéticas; deste modo, Clio não é somente a alegoria simbólica de um gênero de literatura atento ao tempo dos fenômenos sociais e suas causas, a História, mas algo anterior, e que está inoculado também no interior do que se formou como História, ou 
seja, Kléos, a fama proclamada, o brilho de feitos notáveis, que se alça como imagem e logo se expande como mensagem alardeada, Glória. Clio nos convida a perceber a memória também em sua dimensão estética.

\section{Os nomes das Musas}

Eis a grande vantagem de se ler os nomes das Musas em sua expressão performática, como o fez Torrano em sua tradução (v. 75-79); deste modo, temos:
Clio - Glória
Euterpe-Alegria
Talía - Festa
Melpômene - Dançarina
Terpsícore - Alegra-coro
Erato-Amorosa
Polímnia - Hinária
Urânia - Celeste
Calíope - Belavoz

Nas extremidades, dão-se as mãos Clio - Glória, a que conclama e celebra glórias, e Calíope - Belavoz, a que canta o belo verso sagrado (épos), elos que formam uma roda de danças, similar à pintada por Andrea Mantegna em seu extraordinário quadro Parnassus (1497), ou Marte e Vênus. Glória, Alegria, Festa, Dançarina, Alegra-coro, Amorosa, Hinária, Celeste, Belavoz, eis os nomes. Significa pensarmos o kósmos de modo estético, e igualmente as formas culturais da memória, a que hoje chamamos de arte e ciência. Antes da invenção da História, temos a memória, em performance, com a graça de cantigas dançadas, em festa. Desde Maurice Halbwachs (1925), distinguimos História e memória, e vamos, com as Musas, entendendo melhor este fenômeno muito mais poderoso que a escrita do passado, a sua sobrevivência em formas da memória.

Destas Musas, eis-nos, por quinhão, a tratar de Melpômene Dançarina. Por trás do nome, atua o verbo que a põe em movimento, mélpomai, cantar e dançar. Isto, deve-se dizer, todas as Musas e também 
seus cultores, realizam; cantam e dançam, para encanto de Zeus, de todos os deuses e deusas, e da humanidade. As Musas evoluem em círculo, e possuem funções intercambiáveis e complementares. Todas filhas de Zeus e Mnemosýne, significa que há entre elas um nexo de poder e memória. Há unidade e diversidade, em elementos que se reafirmam. Dançarinacantora, todavia, evolui como parte de um grupo de nove moças, e ela dança e canta a melodia ritmada que faz todas evoluírem ritualmente. Talvez mais que isso, devemos entendê-la como a que rege a música e coreografa.

Em época helenística, sob a égide dos filólogos da Biblioteca de Alexandria, cristalizaram-se as atribuições de gêneros e identidades às Musas. Deste modo, o quadro de nomes e atributos passou a comportar a seguinte expressão:

Clio - Glória - História
Euterpe - Alegria - Música
Talía - Festa - Comédia
Melpômene - Dançarina - Tragédia
Terpsícore - Alegra-coro - Dança
Erato - Amorosa - Poesia lírica
Polímnia - Hinária - Poesia coral - Música solene
Urânia - Celeste - Astronomia
Calíope - Belavoz - Poesia épica (retórica)

Os sábios de Alexandria eram sensíveis a tradições orais e textuais que lhes chegaram. Portanto, é razoável examinar a pertinência simbólica e histórica de suas elaborações, incluindo-se os jogos de associações que realizaram com os nomes e funções das Musas. Para o caso de Melpômene, há dois fatos cruciais: primeiramente, sua diferenciação face a Terpsícore, Alegra-coro, que passou a expressar a cultura coreográfica. Segundo, Melpômene associa-se à Tragédia, por oposição à Comédia, da Musa Talía - Festa. Dança e canto associados a Dioniso trágico, eis aí a segunda parte de nossa enquete, em que precisamos examinar a repercussão sobre a história cultural, especialmente em sua expressão iconográfica, onde signos e índices de identidade se desenvolveram. 
A tragédia é culto de Dioniso, e possui origens complexas, que associam as tradições do culto deste deus e também dos lamentos fúnebres a heróis, com predomínio da expressão ritual musicada, cantos e danças. Há também marcas de um mundo pastoral, cultura de camponesas, seus folclores e celebrações. É possível que esta forte marca musical da tragédia grega, em sua origem e mesmo em seu apogeu em Atenas, no século V a.C., justifique sua associação com Melpômene. Note-se que no século V os grandes tragedistas, Ésquilo, Sófocles e Eurípides, desconhecem esta associação entre tragédia e Melpômene, assim como Aristóteles, que não deixaria de comentá-lo em sua poética, se fosse fato conhecido; a associação entre Melpômene e tragédia provavelmente elaborou-se a partir do final do século IV a.C., até tornar-se assunto dos eruditos de Alexandria. Esta inflexão simbólica determinará uma modulação do significado original do nome e da função desta Musa, rumo a uma associação com o espírito da tragédia. Esta mutação simbólica terá grande efeito na fortuna iconográfica de Melpômene, desde a antiguidade.

\section{Iconologia}

A partir do final do século IV a.C., no mundo helenístico, e do século II a.C., no mundo romano, e até os séculos IV e V d.C., ampliase o consumo de imagens, sempre inspiradas pelos mitos gregos. Isto impregna a iconografia numismática, pictográfica (a que temos escasso acesso) e escultórica, mas sobretudo a cultura dos mosaicos e, após o final do século II d.C., também a arte funerária, na escultura de sarcófagos. Em todos esses casos, tratam-se de escolas de artistas muito bem conectadas à cultura e ao gosto das elites aristocráticas, hábeis em conciliar os modelos e memórias da tradição com os gostos e necessidades de seu contexto. São, portanto, artistas que se associam a todos os seus antecessores, inclusive aos avatares arcaicos (Homero e Hesíodo) na interpretação e representação do mito, produzindo novas versões, dotadas de sentido.

Os traços iconográficos das Musas, na arte greco-romana, funcionam em um regime de código, em que as 9 Musas se diferenciam. Esta diferenciação, obedecendo ao princípio da unidade e complementaridade das funções das Musas, não é tão rigorosa como a 
diferenciação dos atributos dos deuses olímpicos; sobram similaridades entre Clio e Calíope, portadoras de um papiro a desenrolar-se, mas há uma progressiva especificação dos índices iconográficos, que permitem a identificação de cada uma. Do ponto de vista da teoria semiótica, há um código Musa, com 9 posições e cerca de duas dezenas de sinais variantes. Melpômene vale-se da associação e contraste com Talía, Musa da comédia, e, portanto, aparece portando a máscara grave, em oposição à máscara de riso sardônico (o riso cômico, bastante irônico). Eis o atributo iconográfico central de Melpômene na iconografia, que permite reconhecê-la com grande facilidade. No célebre mosaico das 9 Musas, em Rhodes, entramada com suas irmãs (as demais 8 Musas), é com esta objetividade iconográfica que aparece Melpômene.

FIGURA 2 - A representação do rosto da Musa Melpômene ao lado de seu mais forte índice de identificação, a máscara trágica. Melpômene, mosaico com máscara, Mosaico das 9 Musas, no Palazzo dei Gran Maestri de Rhodes. Obra romana imperial, encontrada em Cós e transposta para o Palazzo.

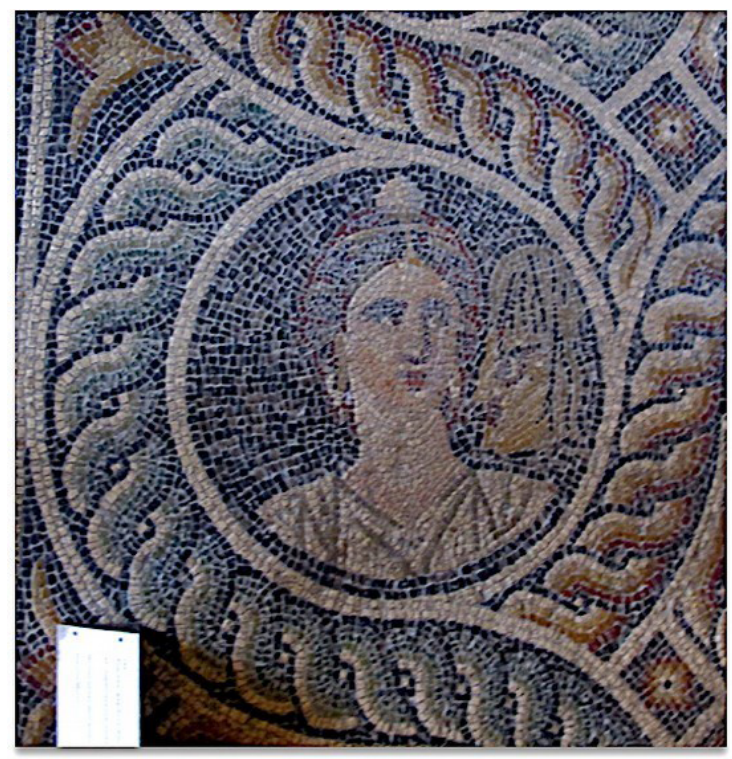

Fonte: Wikipedia Commons, the free media repository, Palazzo dei gran maestri di Rodi, salle delle muse, mosaico delle nove muse da Kos 04 Melpomene. JPG, 2018. 
FIGURA 3 - A graça desta Musa feliz, resoluta e serena.

Melpômene com a máscara e uma espada. Escultura romana, de Monte Calvo, séc. II d.C., na Ny Carlsberg Glyptothek, Copenhagen.

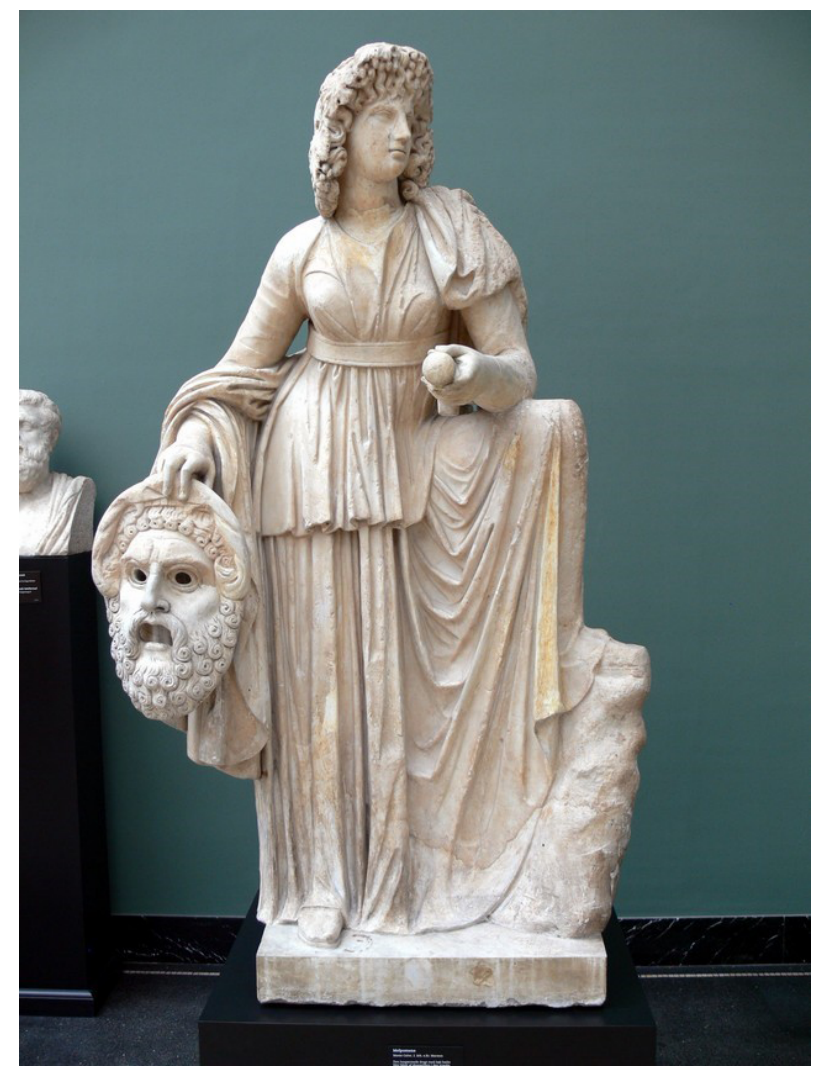

Fonte: Wikipedia Commons, the free media repositor. NY Carlsberg Glyphothek-Melpomene. JPG, 2014.

Ao índice dramatúrgico da Melpômene, Musa trágica, à máscara grave soma-se também uma clava similar à de Héracles, nas esculturas e também em altos-relevos dos sarcófagos. A clava sublinha a relação de Melpômene com o culto heroico, apontando para este aspecto cultural da tragédia ateniense, fortemente vinculada à memória e ao culto heroico. 
FIGURA 4 - Melpômene (canto esquerdo) com máscara trágica e clava, escultura em sarcófago romano, séc. III d.C., na Villa Doria Pamphili.

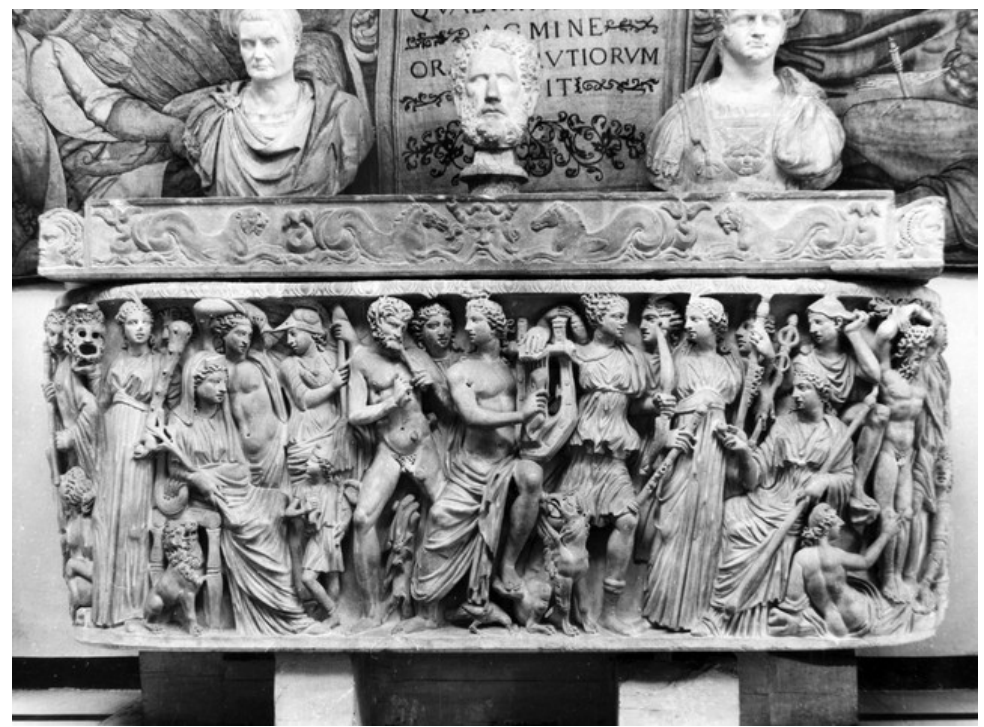

Fonte: The Warburg Institute - Iconographic Database.

Naturalmente, a clava é um elemento pouco coreográfico. Sua adoção acentua o caráter pensativo da arte trágica, uma visão de mundo pessimista, sensível ao sentido aniquilatório e inconciliável do mundo, à reflexão grave. Eis porque algumas figurações de Melpômene adotam também a Pathosformel melancólica, com total abandono da graça cantora e coreográfica. Isto aparece em um sarcófago romano, hoje no Louvre, arte tardia, de grande maturidade e muito vinculada ao mito das Musas. Note-se como Melpômene assume a posição de dar contorno à imagem, na extremidade direita da composição, e observa o interior do friso, com toda a sua narrativa, em uma postura muito reflexiva, com sua perna direita sobre um monturo e a máscara erguida, sobre a cabeça. Ao seu lado, imediatamente, está a Musa que declara relações com o mundo celestial astronômico-astrológico e bastante científico, Urânia. Seu drapeado está estático; canto e dança cedem lugar ao pensamento. 
FIGURA 5 - Melpômene (canto direito) melancólica, escultura em sarcófago romano, Sarcófago das Musas, final do séc. II d.C - início do séc. III, no Museu do Louvre, Paris.

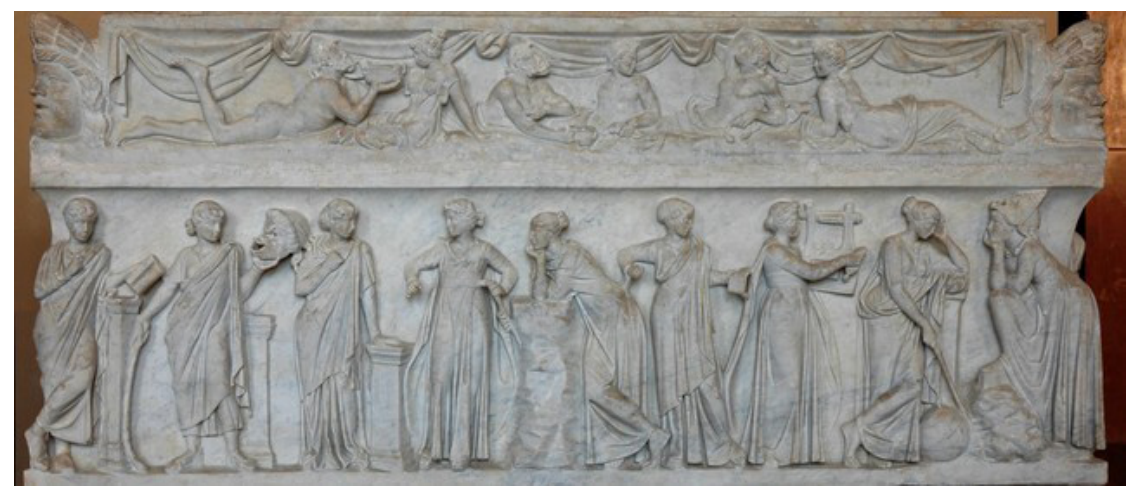

Fonte: Wikimedia Commons, the free media repository. Muses sarcophagus Louvre MR880.jpg, 2015.

FIGURA 6 - Sarcófago das Musas, detalhe.

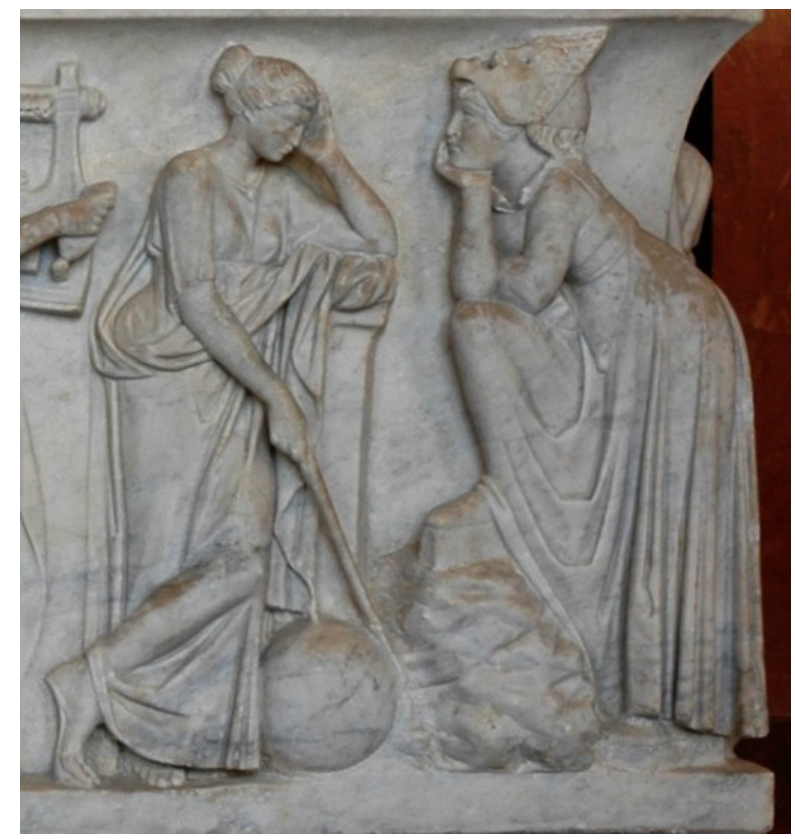

Fonte: Wikimedia Commons, the free media repository. Muses sarcophagus Louvre MR880.jpg, 2015. 
O mosaico de Melpômene, mais célebre, ganha fama por sua imagem central: o poeta Virgílio entronado, com um papiro aberto, com palavras do oitavo verso da Eneida Musa, mihi causas memora, quo numine laeso, quidve - "rememora em mim as causas, qual nume lesado, por qual..."); do lado direito do poeta (esquerda do observador), há uma Musa desenrolando papiro, que muitos identificam como Clio, mas calha melhor vê-la como Calíope, a Musa da poesia épica, gênero do poema que o bardo Mantovano leva no colo, com atributos iconográficos similares a Clio e compatíveis com esta imagem. À esquerda do poeta está uma Melpômene, inequivocamente indiciada pela máscara trágica, que porta em sua mão esquerda. Sua mão direita, todavia, flexiona-se apoiada no trono, para conformar a clássica Pathosformel melancólica, índice muito eficiente para denunciar gravidade pensante.

FIGURA 7 - Mosaico de Virgílio entronado, com um volume da Eneida, ladeado pelas Musas Calíope ou Clio e Melpômene. Século III d.C., descoberta em 1896, em Hadrumetum (Süsah), no Museu Nacional Bardo, Tunísia.

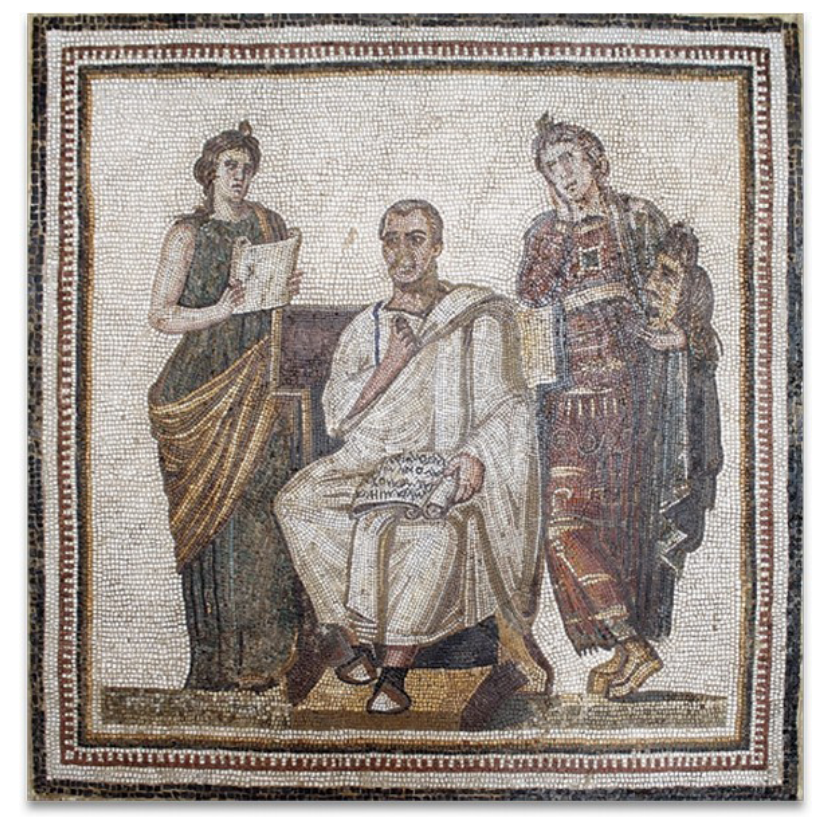

Fonte: Wikimedia Commons Contributors, Virgil mosaic in the Bardo National Museum (Tunis) (12241228546).jpg, 2017. 
Neste mosaico, localizado no Museu Bardo, na Tunísia, em uma cidade romana norte-africana, há detalhes iconológicos instigantes. Primeiramente, Melpômene está mais próxima de Virgílio, diretamente conectada por um ângulo que liga sua visão à mente do poeta. A máscara trágica, igualmente, olha para o ser entronado, e não para nós, espectadores. A outra Musa, por sua vez, Clio ou Calíope, não mira o poeta, mas sim a Melpômene. A memória épica e histórica informa a visão trágica com que o autor da Eneida pensou e retratou a formação mítica e heroica de Roma. Ademais, temos ali a caracterização de um ator trágico, vestindo as botas cuja adoção Horácio (De arte poetica, 278-280) atribui a Ésquilo, os kóthornoi, em pés cruzados que, decididamente, negam a chance de uma dança. Ator: sim, a figura parece ter gênero masculino, como era próprio do teatro antigo, e também pela morfologia de seu rosto, que destoa da delicadeza femínea da face da outra Musa (ainda que amargurada, é delicada). Ainda assim, a figura porta diadema, o que confere sacralidade e a aproxima da representação pura da Musa. O figurino do ator, por sua vez, tem cor púrpura e elaborada ornamentação, de estilo arcaizante, o que sugere a representação ou de uma potência divina ou de um herói de ascendência olímpica, como, e.g., Eneias, ou mesmo um herói identificado ao cenário cartaginês, relacionado ao cenário histórico do mosaico (BUSTAMANTE, 2007, P. 18).

Ocorre que Virgílio não escreveu tragédias, portanto, o artista autor deste mosaico produziu não um retrato ou uma alegoria simples, mas uma complexa leitura das funções de poder e conhecimento que insuflaram a mente da personalidade entronada. A glória de Virgílio é sempre proporcional à glória da gens Julia, de Otávio Augusto, maior beneficiária das meta-representações de propaganda contidas na Eneida, obra-prima das obras comissionadas. $\mathrm{O}$ aristocrata que comissionou esta obra beneficia-se da mesma aura simbólica, de relevância e poder, e conecta a norte-africana Hadrumetum ao cerne da memória e da identidade de Roma. A imagem de uma Musa, já canônica no momento de produção desta imagem, é suporte para uma elaborada reflexão do artista sobre os sentidos da imagem e suas dimensões de saber, memória, arte e poder. 
Cesare Ripa segue engano da tradição e atribui a Virgílio os versos de Catão, em Nomina Musarum (conhecido como As 9 Musas), Melpomene tragico proclamat maesta boatu. (v. 4), ou, na tradução de Francisco de Quevedo (1580-1645), em seu póstumo Parnaso Español (1648), "Melpomene canta fúnebres memorias de personas insignes". É a síntese perfeita, que conecta canto, tragédia, fama e história, e ajuda a compreender porque esta Musa facilmente transita para fora do palco dramático e vai consagrar a gravidade de memórias trágicas.

\section{Recepção}

O mito das Musas nunca desapareceu por completo após o colapso do paganismo greco-romano e ao longo do medievo. Afinal, este mito oferecia uma explicação poderosa, ainda vigente, para o fenômeno da criação artística. Dava-se por inspiração. A Musa soprava dentro do artista, produzindo inspiração em um pulmão de ideias e sentimentos, a mente inspirada. No mundo antigo, este sopro continha também verdades e imagens de um mundo celestial e olímpico, conectado ao mundo histórico em que vivemos por meio do trânsito coreográfico e cognitivo das Musas, que vinham do Olimpo dançando e assim escolhiam a alguns privilegiados para receber a verdadeira imagem de seus cantos. Elas eram autoras da narrativa; originalmente, apenas uma Musa - como Homero refere e evoca no início da Ilíada e da Odisseia. Posteriormente, Hesíodo elaborou esta complexa genealogia de Zeus e Mnemosýne, que conforma uma verdadeira Enéade grega: 9 Musas juntas, dançando e impregnando o mundo com graça e conhecimento.

O artista romântico, mesmo que leve a obra de Homero por tudo, como o jovem e sofrido Werther (GOETHE, 1774), pensa-se como sujeito criador, em arroubos pelo mundo, e busca na paisagem, nas memórias evocadas e no poder de uma alma abrasadora a fonte para sua autoria poética. Mais que inoculação produzida por algumas entidades mágicas, a inspiração romântica é resultado do feito do artista, que segue a sua inclinação de alma e dedica-se a criar obras belas, ou a representá-las em performance. Nesta noção de inspiração e autoria, o mito das Musas jaz lá longe, como ancestral em uma linhagem em que, na era moderna, o 
sujeito emancipado se afirma, e cria com sua inteligência. Ainda assim, o público que ouve as músicas de Mozart facilmente se pergunta "de onde vem tal inspiração"? Este mesmo ouvinte está pronto a associar a fonte da inspiração de artistas maravilhosos ao mundo celestial, ou a um mundo de ideias de natureza divina, o que é uma forma sobrevivente do reconhecimento de que a performance de Arte possui algo sagrado. Mito das Musas, traduzido em outras sensibilidades. Onde andarão as Musas, neste novo cenário?

Antes dos românticos, porém, foi preciso reimaginar os deuses antigos, o que levou imperiosamente a que se conhecesse o mito das Musas, donzelas dançarinas de Zeus. Esta foi a meta perseguida pelos melhores gênios da arte renascentista, de Donatello a Botticelli, de Ghirlandaio a Rafael Sanzio, de Peruggino a Ticiano. O caminho foi aberto pelos aedos florentinos, Dante, Petrarca e Boccaccio, que no século XIV elaboraram os programas e enquetes que levariam ao renascimento do paganismo antigo, em Firenze, nos séculos XV e XVI. Dante figura-se como o herói moderno, a ser guiado pelo maior bardo latino, Virgílio, e o que o move não é amor mariano, mas a paixão e o desejo por sua Beatriz, que o faz atravessar todos os âmbitos do Universo cristão, purgatório, inferno, paraíso. Logo, em sonetos perfeitos, Petrarca vai tratar de sua Laura, idealizada, um amor entre o cortês e o erótico. O erotismo, e igualmente o fogo de uma paixão pelos deuses antigos, apareceu logo na obra de Boccaccio, discípulo confesso de Petrarca (Deorum, 21), a Genealogia deorum gentilium (1350). Além de muita picardia no Decameron (lembrança de 10 dias intensos longe da cidade e seus controles), Boccaccio foi o autor deste tratado sobre os deuses antigos, com um estudo das genealogias, mitos e atributos de grande número de entidades míticas antigas, a partir de Zeus, dos olímpicos e do mundo heroico. Estava aberto o caminho para, no século XV, com o patronato Medici, Firenze tornar-se o epicentro do neopaganismo moderno. Firenze, cidade de erudição literária, filosófica e mística, onde o Hermetismo encontrou novo e potente berço, sob a guarda de Lorenzo e a cultura de Marsilio Ficino e Pico della Mirandolla. A flor da Toscana tornou-se, então, um local de serviço às Musas tão potente como o Parnaso havia sido na Grécia, séculos atrás. 
Como resultado da forte motivação neopagã da arte renascentista italiana, revitalizaram-se os imaginários de Afrodite, Dioniso, Hermes, Apolo e Ártemis, e dos demais olímpicos: Palas Atena, Ares, Hera, Hécate, Posido e Hades, bem como de muitos heróis, entidades tópicas do mito e nomes de augustos poetas, algo divinizados pela memória. Da leitura de Homero e Hesíodo, renasceu também o conhecimento dos modos mais antigos do pensamento mítico grego. Daí decorreu o renascimento da visão das Musas, e o modo soberbo com que artistas viram, ainda melhor que os antigos, a graça e a potência deste mito. Embora este fato cultural (o renascimento da imagem das Musas) apareça em muitas obras, há duas pinturas que revelam o reencontro com a noção apresentada no início deste ensaio, as Musas em dança de roda, no centro de um universo habitado por deuses olímpicos, um pedaço da paisagem dramatizado para servir de cenário a uma coreografia sagrada: a dança das Musas, no já referido quadro Parnassus de Andrea Mantegna, e a dança paradigmática, com lábaros esvoaçantes contendo nomes legendados, na obra de Baldassare Peruzzi.

FIGURA 8 - Andrea Mantegna, (1431-1506), Parnassus, 1497, Museu do Louvre.

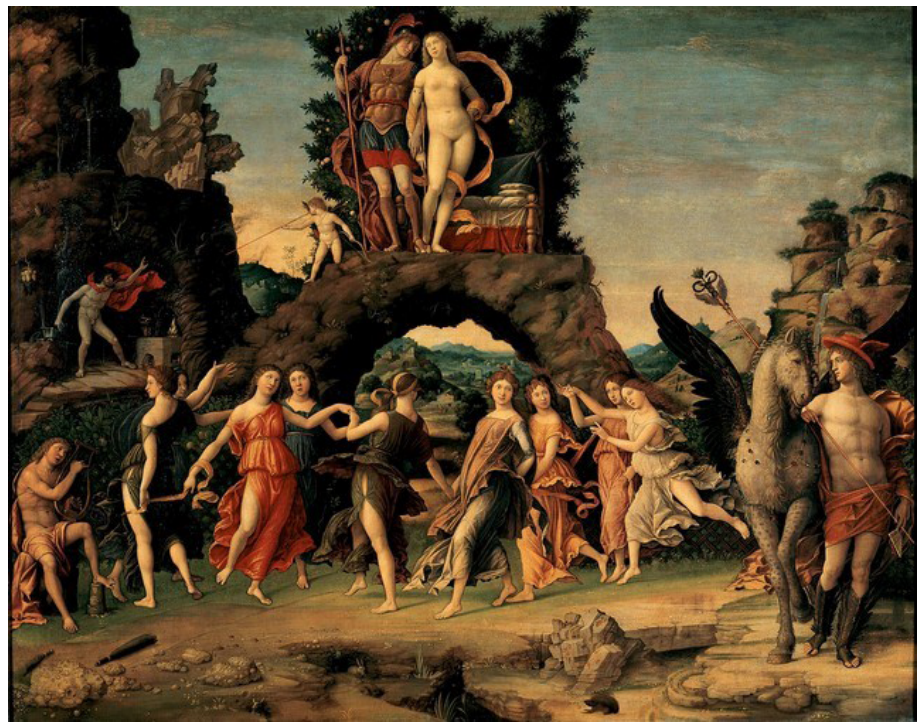

Fonte: Wikimedia Commons, the free media repositor. Le Parnasse, by Andrea Mantegna, from C2RMF retouched.jpg, 2019. 
FIGURA 9 - Baldassare Peruzzi (1481-1536), Dança das Musas, 1514-23, Palazzo Pitti, Firenze.

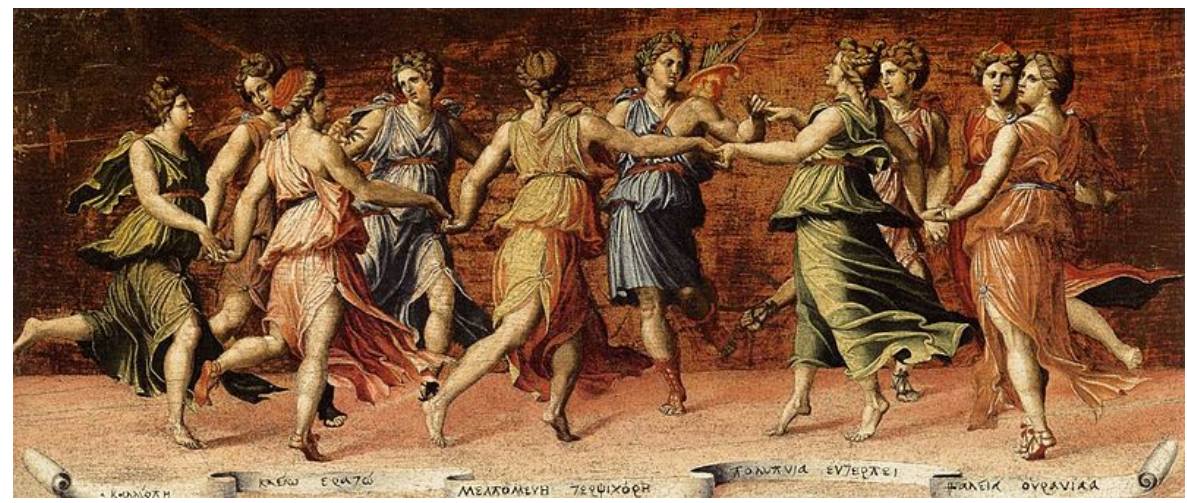

Fonte: Wikimedia Commons, the free media repository, Baldassare PeruzziApollo and the Muses - WGA17365.jpg, 2018.

A editio princeps (primeira edição impressa) de Homero é de 1488 e 1489, editada pelo erudito grego Demetrius Calchondyles e impressa por Bartolommeo di Libri, a expensas dos irmãos Nerli. Foi a primeira edição impressa de um clássico grego em seu idioma; em 1495, Aldus Manutius publicou a obra completa de Hesíodo, em Veneza. Ambas edições antecedem as pinturas de Andrea Mantegna (1497) e Baldessare Peruzzi (1514-23), e atingem comunidades de leitores ávidos por esta visão do sagrado, imaginada por pintores dotados de sensibilidade textual arrebatadora. As Musas reaparecem, no Renascimento, como potências de intensa pulsão coreográfica e função cósmica axial, eixo do mundo. Assim conforma-se a dança cerimonial descrita por Hesíodo, e assim estão na obra de Mantegna, compondo o centro e eixo de ações sacras que dão ordem e dinâmica à imagem, em torno da imagem central das Musas dançando. O ponto culminante da cena representada é o episódio de Ares e Afrodite, junto a um convidativo leito, no topo de uma colina em arco, o círculo cósmico; a partir dali, em um trajeto circular pela direita (do observador), encontra-se Hermes, que olha a cena, em vias de partir montado em Pégaso e, no lado oposto, Apolo (à esquerda), tocando lira; seguindo o círculo, chega-se a Hefesto, agastado com o que vê, junto a sua fornalha, em uma gruta. Eros une princípio e fim da narrativa, com 
uma zarabatana amorosa. Esta obra, maravilhosa passagem do verso à imagem, é muito próxima dos versos de Hesíodo, e assombra a quem conhece as Musas, seus mitos e ritos, suas letras e imagens.

\section{Museu}

Por fim, o que deve significar a Musa Melpômene para quem a vê em um Museu? As arquiteturas de Museus, bem como a semiologia das obras de arte, estão repletas de representações das Musas, demarcando e elevando o território das Artes. É previsível, portanto, que frequentadores de Museus encontrem em sua casa as Musas, entre as quais, Melpômene. Não há Musa para a pintura ou a escultura, pois aquele coro de dançarinas reunia artes e conhecimentos performáticos, mas há pintura e escultura para as Musas, e muita, e fazem parte dos epifenômenos das entidades imaginadas.

Encontrar Melpômene significa abrir-se a uma dupla ou tripla reflexão, que pode atingir a percepção e interpretação de todo o Museu, ou de uma quantidade significativa de obras. Primeiramente, ao ver Musa, lembramos da origem sagrada e coreográfica das artes, e o quanto estas nos conectam a visões transcendentais do mundo e da condição humana. Sabemos que as Musas são chave para um processo de inspiração em que se abrem visões mágicas de um cosmos regido por potências que inoculam saber e beleza, e podemos esperar algo desta experiência, no domínio das Musas. Este é o primeiro estágio da experiência sensível provocada pela visão das Musas, pelo encontro com sinais daquele mundo mágico: inaugurar um rito em que nos abrimos à sensibilidade sagrada e potente com que a memória nos conecta à potência da Arte, memória, conhecimento, o sagrado, a beleza e suas muitas formas, aos passos leves e musicais de coreografias cósmicas, à fonte transcendental e imanente da Arte.

Melpômene, em particular, convida nossa sensibilidade para o seu duplo campo semântico, primeiramente, como Dançarina que foi, desde os tempos de Hesíodo; dancemos, pois, mesmo que mentalmente, pensando nas melodias que animam boa parte das imagens que vemos em Museus. Após dar início à coreografia, esta Musa nos leva à tragédia, 
com que a iconologia histórica a consagrou. Diante da sensibilidade trágica, Melpômene nos conduz a uma reflexão sobre a gravidade do mundo, sobre os limites e padecimentos da condição humana, sobre a difícil superação de certos conflitos que a arte pode, com coragem, representar. Melpômene não se restringe à tragédia ou à pintura, mas significa o momento em que a dança cede a um olhar melancólico, e com ele projeta-se um grau traumático nas relações entre homem e nume, entre memória e vida, entre gozo e pensamento. Melpômene, Musa dançarina e potência trágica, condutora em um cosmos que a Arte contempla, coreografa e reflete, Melpômene, com a profundidade de um mito do mundo feito poesia e imagem.

FIGURA 10 - Melpômene. Óleo sobre tela de Joseph Fagnani, 1869, no MET-NY.

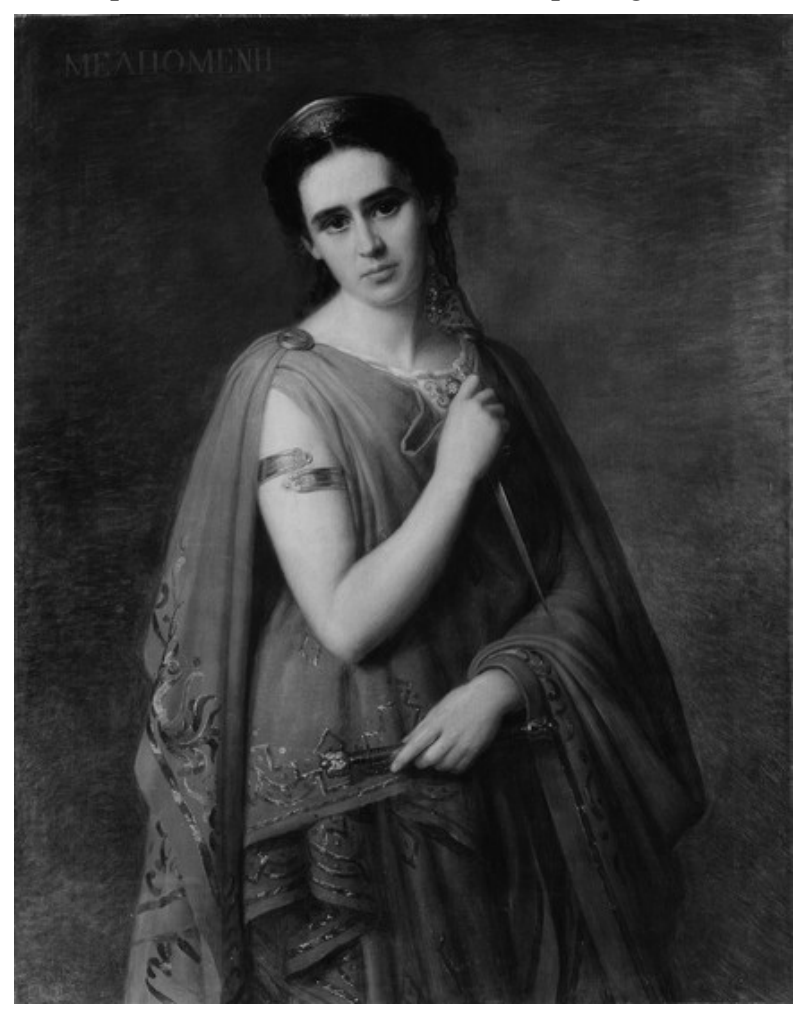

Fonte: Wikimedia Commons, the free media repository. Melpomene (by Joseph Fagnani).jpg, 2017. 


\section{Referências}

APOLLO Mousai Louvre L27.jpg. In: Wikimedia Commons, 31 jan. 2019. Disponível em: https://commons.wikimedia.org/w/index.php? title=File:Apollo_Mousai_Louvre_L27.jpg\&oldid=337181818. Acesso em: 19 ago. 2019.

BOCCACCIO, G. Genealogy of the pagan gods. Tradução e texto crítico editado por Jon Solomon. Cambridge: Harvard University Press, 2011.

BUSTAMANTE, R. M. da C. Fazem-me lembrar, ó Musa... Leituras do mosaico Virgílio e as Musas. Phoînix, Rio de Janeiro, v. 13, n.1, p. 292-313, 2007.

GODS \& MYTHS In: The Warbug Institute: Iconographic Database, (C)2018. Disponível em: https://iconographic.warburg.sas.ac.uk/vpc/ VPC_search/pdf_frame.php?image $=00036552$. Acesso em: 19 ago. 2019.

GOETHE, Johann Wolfgang von. Die Leiden des jungen Werthers. Leipzig, Weygandschen Buchhandlung, 1774.

HALBWACHS, M. Les cadres sociaux de la mémoire. Paris: Librairie Félix Alcan, 1925.

HESÍODO. Teogonia, a origem dos deuses. Estudo e tradução de Jaa Torrano. São Paulo: Iluminuras, 1995.

LA PARNASSE, by Andrea Mantegna, from C2RMF retouched. jpg. In: Wikimedia Commons, the free media repository, 12 jun. 2019. Disponível em: https://commons.wikimedia.org/w/index. php?title=File:La_Parnasse,_by_Andrea_Mantegna,_from_C2RMF_ retouched.jpg\&oldid $=354228341$. Acesso em: 19 ago. 2019 .

MELPOMENE (by Joseph Fagnani).jpg. In: Wikimedia Commons, the free media repository, 12 abr. 2017. Disponível em: https://commons. wikimedia.org/w/index.php?title=File:Melpomene_(by_Joseph_ Fagnani).jpg\&oldid=240611829. Acesso em: 19 ago. 2019.

MUSES sarcophagus Louvre MR880.jpg. In: Wikimedia Commons, the free media repository, 19 jan. 2015. Disponivel em: https://commons. wikimedia.org/w/index.php?title=File:Muses_sarcophagus_Louvre_ MR880.jpg\&oldid=147097781. Acesso em: 19 ago. 2019. 
PALAZZO dei gran maestri di rodi, sala delle muse, mosaico delle nove muse da kos 04 melpomene.JPG In: Wikimedia Commons, the free media repository, 13 jan. 2018. Disponível em: https://commons.wikimedia. org/w/index.php?title=File:Palazzo_dei_gran_maestri_di_rodi,_sala_ delle_muse, mosaico_delle_nove_muse_da

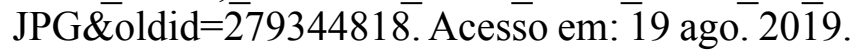

PERUZZI, Baldassare - Apollo and the Muses - WGA17365.jpg. In: Wikimedia Commons, the free media repository, 14 jul. 2018 Disponível em: https://commons.wikimedia.org/w/index. php?title=File:Baldassare_Peruzzi_-_Apollo_and_the_Muses_-_ WGA17365.jpg\&oldid $=311 \overline{1} 73530$. Acesso em: $\overline{1} 9$ ago. $20 \overline{1} 9$.

RIPA, C. Iconologia. Madrid: Ediciones Akal, 2016. v. I e II

VIRGIL mosaic in the Bardo National Museum (Tunis) (12241228546). jpg. In: Wikimedia Commons, the free media repository, 6 jun. 2017. Disponível em: https://commons.wikimedia.org/w/index. php?title=File:Virgil_mosaic_in_the_Bardo_National_Museum (Tunis)_(12241228546).jpg\&oldid $\overline{\mathrm{d}}=24 \overline{6} 76638 \overline{4}$. Acesso em: 19 ago. 2019.

Recebido em: 17 de março de 2019.

Aprovado em: 6 de junho de 2019. 